\title{
Seminoma presented as testicular rupture: Case report and literature review
}

\author{
Rahul Lunawat, MD; Marius Craciun, MD; Savvas Omorphos, MD; Philip M.T. Weston, MD; Shekhar C. Biyani, MD
}

Department of Urology, Pinderfields Hospital, Wakefield, Mid Yorkshire NHS Trust, UK

Cite as: Can Urol Assoc J 2014;8(9-10):e749-51. http://dx.doi.org/10.5489/cuaj.2194 Published online October 22, 2014.

\section{Abstract}

Rupture of the testis as a result of blunt trauma is rarely seen in daily urological practice. We report an unusual case of incidental seminoma diagnosed after surgical exploration and subsequent orchidectomy of a severed testis following testicular injury as a result of trivial blunt trauma. This case highlights the inability of investigative tools, such as a scrotal ultrasound, in distinguishing an underlying tumour in the presence of testicular parenchymal damage. We therefore advocate a high index of clinical suspicion for co-existing pathology in cases of testicular rupture secondary to an insignificant blunt trauma to the scrotum.

\section{Introduction}

Scrotal trauma accounts for less than $1 \%$ of all trauma related injuries, because of the anatomical location and mobility of the scrotum. ${ }^{1}$ Patients with scrotal trauma present with acute pain; an accurate early diagnosis is necessary to prevent loss of the testis.

We report a case of incidental testicular tumour diagnosed after surgical exploration of a severed testis following testicular injury as a result of trivial blunt trauma. Intrascrotal rupture of a testicular cancer is rare and there have only been 5 reported cases of testicular tumour rupture in the last 60 years.

\section{Case report}

A 42-year-old male presented to the emergency department after being kicked in the scrotum by his 2-year-old daughter while playing. The only symptom experienced was mild discomfort. The scrotal discomfort persisted for more than 24 hours, hence medical attention was sought. Interestingly, he informed us that during his teens he had a vague episode of testicular discomfort, but dismissed this as an isolated episode. On clinical examination, a mildly tender, swollen right testis was noted, double in size compared with the contralateral side, with obvious ecchymosis around the scrotal skin towards the base of the penis and right groin. There was no associated hydrocele. Ultrasonography of the scrotum was performed to rule out testicular haematoma or ruptured tunica albuginea. The Doppler ultrasonography suggested a breach in the tunica albuginea and showed a large heterogeneous echo-texture with very little vascularity in the right lower testicle consistent with a hematoma. (Fig. 1). Surgical exploration was undertaken through the scrotal approach, using a midline incision. During surgery, he was found have a severed unsalvageable right testis hence an orchidectomy was performed. The procedure and the subsequent recovery were uneventful.

Histology surprisingly revealed an incidental ruptured classical seminoma, pT2, $43 \times 62 \times 75 \mathrm{~mm}$ in size. The patient was referred to the Oncology Department for further management. A staging computed tomography scan did not show any signs of metastasis; the tumour markers, alpha retoprotein and the human chorionic gonadotropin, were negative on postoperative day 8 . Lactate dehydrogenase $(\mathrm{LDH})$ was elevated at $352 \mathrm{IU} / \mathrm{L}$. After 3 cycles of BEP (bleomycin, etoposide and cisplatin) at the 12 months follow-up, there were no signs of recurrence of his primary disease and LDH was within normal limits.

\section{Discussion}

Blunt scrotal trauma infrequently leads to severe damage of the scrotal contents as studies have demonstrated that about $50 \mathrm{~kg}$ of force is required to rupture the testis. ${ }^{2}$ Testicular rupture, intra-testicular hematoma, testicular avulsion, or epididymal injuries have all been reported as a direct consequence of significant blunt scrotal trauma. ${ }^{3}$

Clinical examination is often limited because of scrotal pain and swelling, and may lead to the misdiagnosis of severe injuries and in particular testicular rupture. These 
misdiagnoses have been demonstrated to increase orchidectomy rates ${ }^{3}$ and long-term morbidity, such as atrophy and infertility. Cass and Luxemberg ${ }^{3}$ reported an orchidectomy rate of $6 \%$ with early exploration versus $45 \%$ with delayed surgery. Early surgical treatment of scrotal trauma is recommended by most authors. ${ }^{4}$ Although, a thorough history and detailed clinical examination are essential for a precise diagnosis, ultrasonography with Doppler flow evaluation is the investigation of choice to detect scrotal abnormalities. ${ }^{1}$ It is a non-invasive, simple and fast diagnostic tool with high accuracy in evaluating the integrity of scrotal contents, testicular integrity and blood flow. In their series of 65 patients, Buckley and McAninch found a sensitivity of $100 \%$ and a specificity of $95 \%$ for ultrasonography in the diagnosis of testicular rupture. ${ }^{4} \mathrm{Kim}$ and colleagues demonstrated that loss of definition of the tunica albuginea is the only significant predictor for the diagnosis of testicular rupture in patients with blunt scrotal trauma. ${ }^{5}$

There have only been 5 cases of testicular tumour rupture described in the literature in the last 60 years (Table 1). In our case, the patient had a history of a trivial trauma 24 hours before his presentation and did not have any metastasis on the staging imaging.

Intrascrotal rupture of a testicular cancer is rare, and no general agreement exists regarding how to manage this condition in the post-orchidectomy setting. The standard treatment of primary testicular cancer remains radical high inguinal orchidectomy; although, several studies suggest that scrotal violation does not impart a significantly worse overall prognosis with current multimodal therapy. ${ }^{6}$ We recommend that an inguinal approach for testicular rupture secondary to light trauma be considered if there is any suspicion of associated malignancy.

The presence of seminoma in this case was missed for several reasons. There were no red flag symptoms or signs

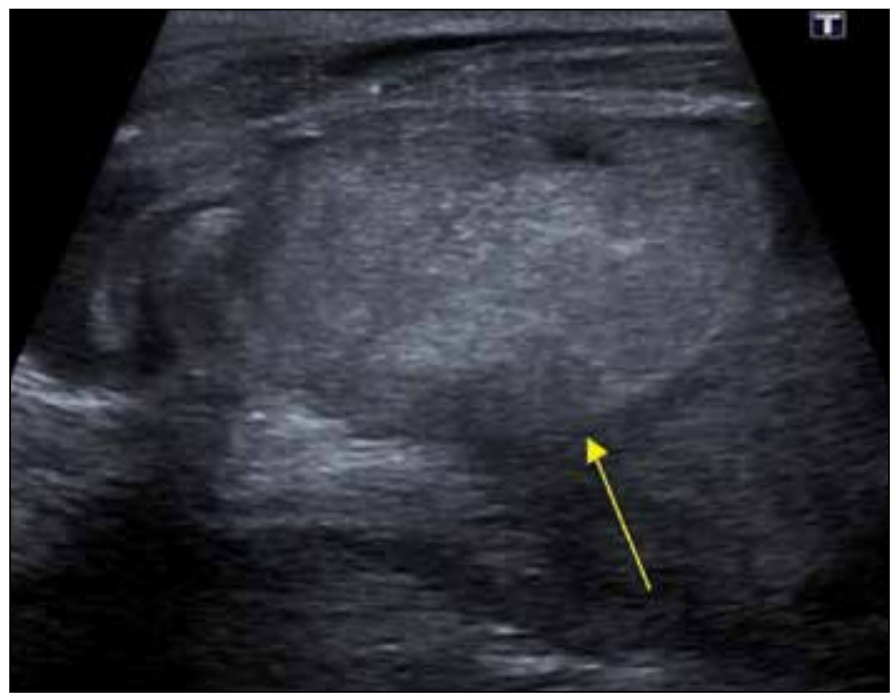

Fig. 1. Ultrasound finding of breach in tunica albuginea.

in the patient's history or during clinical examination to alert the clinicians involved. Ultrasonographic findings of testicular rupture showed a breach in tunica albuginea and possible the surrounding hematoma with a mixed echogenic pattern hindering the underlying seminoma.

\section{Conclusion}

This is a rare case that demonstrates the importance of maintaining a low threshold and high index of clinical suspicion for co-existing pathology for any trivial blunt injury to the scrotum that may result in testicular rupture. It highlights the limitations of clinical history and examination in this scenario. Even in the presence of precise diagnostic tools, a small testicular tumour may still be masked by the degree of damage to adjacent testicular parenchymal tissue.

\begin{tabular}{|c|c|c|c|c|c|c|c|c|}
\hline Reference & Year & Age & $\begin{array}{c}\text { Initial } \\
\text { diagnosis }\end{array}$ & $\begin{array}{l}\text { History of } \\
\text { trauma }\end{array}$ & Treatment & Histology & $\begin{array}{c}\text { Adjuvant } \\
\text { treatment }\end{array}$ & Follow-up \\
\hline Cassie $^{7}$ & 1956 & 22 & Hematocele & $\begin{array}{c}\text { Trivial trauma } \\
2 \text { weeks } \\
\text { previously }\end{array}$ & $\begin{array}{c}\text { Scrotal } \\
\text { exploration } \\
\text { followed } \\
\text { by Inguinal } \\
\text { orchidectomy }\end{array}$ & Seminoma & Radiotherapy & NR \\
\hline Cujatar ${ }^{8}$ & 1972 & 18 & $\begin{array}{l}\text { Testicular } \\
\text { torsion }\end{array}$ & No & $\begin{array}{l}\text { Inguinal } \\
\text { orchidectomy }\end{array}$ & Teratoma & Radiotherapy & 18 months \\
\hline Liu $^{9}$ & 2001 & Neonate & $\begin{array}{l}\text { Testicular } \\
\text { torsion }\end{array}$ & No & $\begin{array}{l}\text { Orchidectomy } \\
\text { (not specified) }\end{array}$ & $\begin{array}{c}\text { Mature cystic } \\
\text { teratoma }\end{array}$ & $n / r$ & 8 months \\
\hline $\begin{array}{l}\text { La } \\
\text { Montagne }^{10}\end{array}$ & 2002 & 19 & $\begin{array}{l}\text { Testicular } \\
\text { tumour }\end{array}$ & No & $\begin{array}{c}\text { Inguinal } \\
\text { orchidectomy }\end{array}$ & $\begin{array}{l}\text { Predominantly } \\
\text { yolk sac } \\
\text { tumour }\end{array}$ & Chemotherapy & 6 months \\
\hline Luchey ${ }^{11}$ & 2009 & 24 & $\begin{array}{l}\text { Testicular } \\
\text { rupture }\end{array}$ & $\begin{array}{c}\text { Crushed by } \\
\text { tree }\end{array}$ & $\begin{array}{c}\text { Inguinal } \\
\text { orchidectomy }\end{array}$ & Mixed GCT & Chemotherapy & 12 months \\
\hline
\end{tabular}


Competing interests: Dr. Lunawat, Dr. Craciun, Dr. Omorphos, Dr. Weston and Dr. Biyani all declare no competing financial or personal interests.

This paper has been peer-reviewed.

\section{References}

1. Rao MS, Ariun K. Sonography of scrotal trauma. Indian I Radiol Imaging 2012;22:293-7. http://dx.doi. org/10.4103/0971-3026.111482

2. Saleh D, Shaw D, Biyani CS. A dog bite to the adult scrotum. Can Urol Assoc J 2009;3:E64-6.

3. Cass AS, Luxenberg M. Testicular injuries. Urology 1991;37:528-30. http://dx.doi.org/10.1016/00904295(91)80317-7

4. Buckley JC, MCAninch JW. Use of ultrasonography for the diagnosis of testicular injuries in blunt scrotal trauma. J Urol 2006;175:175-8. http://dx.doi.org/10.1016/S0022-5347(05)00048-0
5. Kim SH, Park S, Choi SH, et al. Significant predictors for determination of testicular rupture on sonography: A prospective study. J Ultrasound Med 2007;26:1649-55.

6. Capelouto CC, Clark PE, Ransil BJ, et al. A review of scrotal violation in testicular cancer: Is adjuvant local therapy necessary? I Urol 1995;153:981-5.

7. Cassie GF. Rupture of the testis: Seminoma. Br J Urol 1956;28:283. http://dx.doi.org/10.1111/ j.1464-410X.1956.tb04772.x

8. Cutajar CL. Spontaneous rupture of testicular teratoma. Br Med J 1972;1:154-5. http://dx.doi. org/10.1136/bmi.1.5793.154

9. Liu SP, Huang SW, Lin KH, et al. Ruptured cystic teratoma of the testis in a neonate. J Formos Med Assoc 2001;100:779-81.

10. LaMontagne AE Jr. Spontaneous rupture of a testicular tumor. J Urol 2002;167:1787-8. http://dx.doi. org/10.1016/S0022-5347(05)65205-6

11. Luchey A, Rogers A, Saunders SE, et al. Blunt testicular trauma results in rupture of mixed germ cell tumor. Can J Urol 2009;16:4955-7.

Correspondence: Dr. Marius Craciun, Department of Urology, Pinderfields Hospital, Wakefield, Mid Yorkshire NHS Trust, UK; mariusemil.craciun@yahoo.com 